\title{
Transoral Endoscopic Thyroidectomy via Vestibular Approach \\ A series of the first ten cases in Iraq
}

"Sadq G. Kadem, ${ }^{1}$ Sarmad M. Habash, ${ }^{1}$ Ali H. Jasim²

$$
\text { استئصال الغدة الدرقية بالمنظار عن طريق دهليز الفم ألمات فئم العراق }
$$

$$
\text { صادق غالب كاظم، سرمد مانع حبش، علي حسين جاسم }
$$

ABSTRACT: Transoral endoscopic thyroidectomy was first described as an experimental sublingual approach. This approach was modified to a vestibular approach to avoid complications. In this report, we describe the results of the first ten cases of a transoral endoscopic thyroidectomy via vestibular approach (TOETVA) performed in Iraq. All operations were performed at Al Shifa General Hospital, Basrah, Iraq, in 2017 using three laparoscopic ports inserted at the oral vestibule. One out of ten patients underwent a near total thyroidectomy, the remaining cases underwent thyroid lobectomies. The average operative time was 113.5 minutes and the average duration of hospital stay was 41.9 hours. One case of mild cervical emphysema and one case of temporary mental nerve palsy were reported but both were treated conservatively without permanent sequelae. In conclusion, TOETVA is a safe, feasible procedure with an excellent cosmetic outcome when the patients are selected carefully.

Keywords: Thyroidectomy; Endoscopy; Mouth; Robotics; Case Reports; Iraq

الملخص: تم البدء وصف أول عملية استئصال الغدة الدرقية بـالمنظار عن طريق الفم بإستخدام أسلوب جراحة تحت اللسان كطريقة

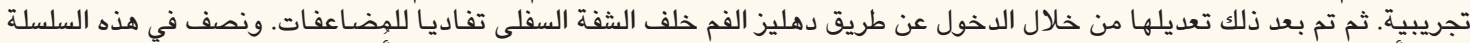

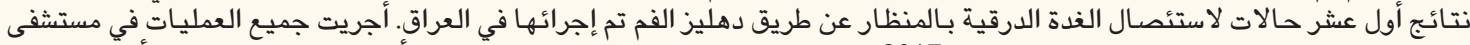

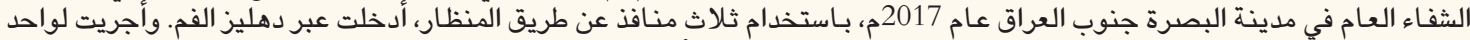

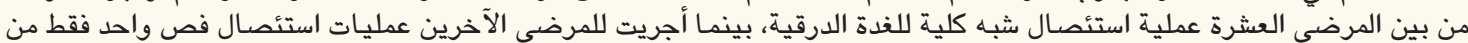

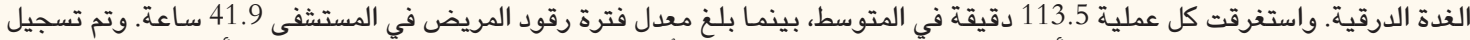

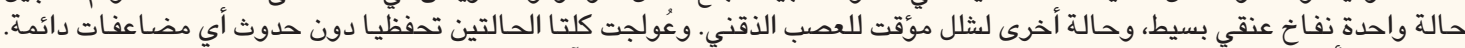

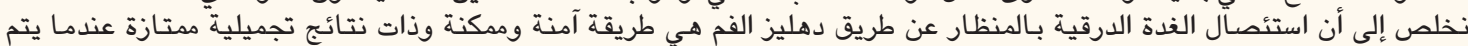
اختيار المرضى المناسبين بعناية.

$$
\text { الكلمات المفتاحية: استئصال الغدة الدرقية؛ التنظير؛ الفم؛ الروبوتات؛ تقارير حالات؛ العراق. }
$$

$\mathrm{W}$ TZEL ET AL. FIRST DESCRIBED TRANSORAL endoscopic thyroidectomy as an experimental sublingual approach in 2007. ${ }^{1}$ Karakas et al. evaluated this approach in a series of patients for transoral parathyroid surgery and suggested that while it is feasible, it is poorly accepted by patients and it has a high complication rate. ${ }^{2}$ In 2012, Nakajo et al. changed the site of the port entry from sublingual to vestibular and reported that one patient had recurrent laryngeal nerve palsy as a complication of this approach. ${ }^{3}$

In 2015, Anuwong reported the first large cohort of 60 patients that had been operated on using transoral endoscopic thyroidectomy via vestibular approach (TOETVA) with no permanent complications. Thevestibular approach was modified by changing the positions of the vestibular ports to a high and more lateral area in the vestibule near the angle of the mouth. ${ }^{4}$
Navarra et al. described the patient selection criteria for surgeons who are less experienced with the TOETVA procedure. ${ }^{5}$ These include: (1) strong motivation for scar-free surgery; (2) young and healthy patients able to tolerate the relatively long procedure; (3) a single benign thyroid nodule with a size of approximately $3 \mathrm{~cm}$ that is not posteriorly located so that it is easy to handle and endoscopically dissect; and (4) males with laryngeal prominence and obese patients with short necks should be avoided because surgeons need more experience due to the difficulty of the dissection. The authors also stipulated that a right-handed surgeon should start by operating on right-sided thyroid nodules because the left lobectomy is more challenging for a right-handed surgeon. In this report, we describe the results of the first ten cases of TOETVA performed in Iraq. 

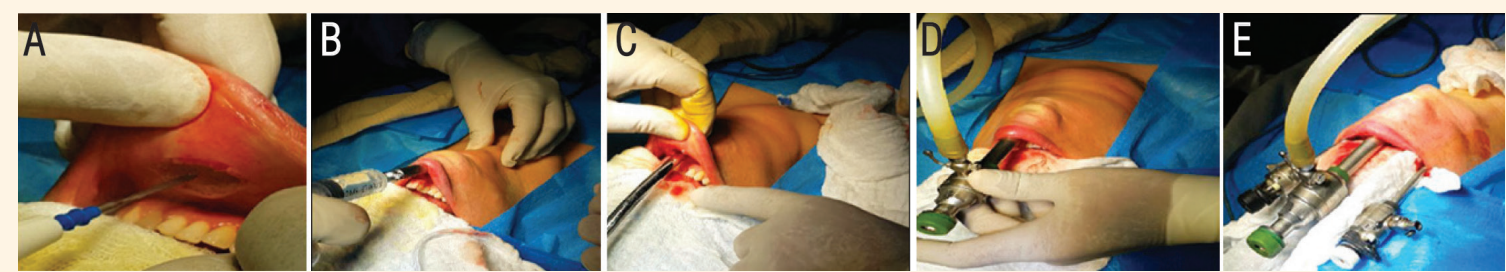

Figure 1: Photographs of the surgical procedure steps. A: Transverse vestibular incision $(10 \mathrm{~mm})$ was made in the midline and extended to the mandible symphysis. B: Sub-platysmal hydrodissection was performed on three axes. C: Blunt dissection of the sub-platysmal plane with a blunt dilator on the same three axes as the hydrodissection. D: A $10 \mathrm{~mm}$ central trocar for the camera was placed through the vestibular incision and carbon dioxide insufflation was done. E: Two additional $5 \mathrm{~mm}$ trocars were placed through vertical incisions in the most lateral aspects of either side of the vestibule nearest to the edges of the mouth.

Table 1: Demographics of ten patients who underwent transoral endoscopic thyroidectomy via vestibular approach at Al Shifa General Hospital, Basrah, Iraq

\begin{tabular}{|c|c|c|c|c|c|}
\hline \multirow[t]{2}{*}{ Case } & \multirow{2}{*}{$\begin{array}{c}\text { Age } \\
\text { in } \\
\text { years }\end{array}$} & \multirow{2}{*}{$\begin{array}{c}\text { BMI } \\
\text { in } \\
\mathrm{kg} / \mathrm{m}^{2}\end{array}$} & \multicolumn{2}{|c|}{$\begin{array}{l}\text { Pre-operative } \\
\text { ultrasound findings }\end{array}$} & \multirow{2}{*}{$\begin{array}{c}\text { Pre- } \\
\text { operative } \\
\text { cytology }\end{array}$} \\
\hline & & & Findings & $\begin{array}{c}\text { Largest } \\
\text { dimension } \\
\text { of thyroid } \\
\text { nodule or } \\
\text { lobe in } \mathrm{cm}\end{array}$ & \\
\hline 1 & 25 & 20 & $\begin{array}{l}\text { Bilateral multi- } \\
\text { nodular } \\
\text { Right lobe } \\
\text { Left lobe }\end{array}$ & $\begin{array}{l}3.6 \\
3.4\end{array}$ & $\begin{array}{l}\text { Cystic colloid } \\
\text { nodules }\end{array}$ \\
\hline 2 & 28 & 23 & $\begin{array}{l}\text { Right solitary } \\
\text { nodule }\end{array}$ & 3.2 & $\begin{array}{l}\text { Adenomatoid } \\
\text { nodule }\end{array}$ \\
\hline 3 & 24 & 22 & $\begin{array}{l}\text { Right solitary } \\
\text { nodule }\end{array}$ & 2.8 & $\begin{array}{l}\text { Adenomatoid } \\
\text { nodule }\end{array}$ \\
\hline 4 & 30 & 25 & $\begin{array}{l}\text { Right solitary } \\
\text { nodule }\end{array}$ & 3.0 & $\begin{array}{l}\text { Adenomatoid } \\
\text { nodule }\end{array}$ \\
\hline 5 & 36 & 20 & $\begin{array}{l}\text { Right solitary } \\
\text { nodule }\end{array}$ & 2.2 & $\begin{array}{l}\text { Adenomatoid } \\
\text { nodule }\end{array}$ \\
\hline 6 & 27 & 24 & $\begin{array}{l}\text { Right solitary } \\
\text { nodule }\end{array}$ & 3.4 & $\begin{array}{l}\text { Adenomatoic } \\
\text { nodule }\end{array}$ \\
\hline 7 & 33 & 26 & $\begin{array}{l}\text { Right solitary } \\
\text { nodule }\end{array}$ & 2.6 & $\begin{array}{l}\text { Adenomatoid } \\
\text { nodule }\end{array}$ \\
\hline 8 & 40 & 23 & $\begin{array}{l}\text { Right solitary } \\
\text { nodule }\end{array}$ & 2.0 & $\begin{array}{l}\text { Adenomatoid } \\
\text { nodule }\end{array}$ \\
\hline 9 & 29 & 25 & $\begin{array}{l}\text { Right solitary } \\
\text { nodule }\end{array}$ & 3.3 & $\begin{array}{l}\text { Adenomatoid } \\
\text { nodule }\end{array}$ \\
\hline 10 & 31 & 21 & $\begin{array}{l}\text { Right solitary } \\
\text { nodule }\end{array}$ & 2.1 & $\begin{array}{l}\text { Adenomatoid } \\
\text { nodule }\end{array}$ \\
\hline Average & 30.3 & 22.9 & - & 2.87 & - \\
\hline
\end{tabular}

$B M I=$ body mass index.

\section{Case Report}

All operations were conducted at Al Shifa General Hospital, Basrah, Iraq in 2017. All surgeons had at least ten years' experience in open thyroid surgery and in general laparoscopic surgery. The inclusion criteria was as follows: (1) female patients that are young and healthy with strong motivation for scar-free surgery; (2) patients with a benign solitary thyroid nodule with the largest dimension between $2-4 \mathrm{~cm}$; (3) patients with a benign multinodular goitre where each thyroid lobe not exceeding $4 \mathrm{~cm}$ in the largest dimension on preoperative ultrasound-to allow for easy endoscopic dissection and extraction through the vestibular wound; and (4) preferably, patients with right-sided pathology since the surgeon was right-handed. All male patients, patients with thyroiditis or hyperthyroidism, obese patients, patients with short necks, those with a history of neck irradiation or previous neck surgery and patients with mouth sores and infections were excluded.

All patients were asked to gargle with chlorhexidine mouthwash three times a day for three days prior to surgery. The patients were admitted to the hospital one day pre-surgery for routine investigations and preparation for general anaesthesia. A flexible fibre-optic laryngoscopy was performed to confirm normal recurrent laryngeal nerve function.

The surgical approach followed the operative steps described by Anuwong. ${ }^{4}$ During induction of general anaesthesia with endotracheal intubation through the mouth, the patient received intravenous prophylactic antibiotics, either amoxicillin $(1 \mathrm{~g})$ or clindamycin $(900 \mathrm{mg})$ in cases of an allergy to penicillin.

The steps in the surgical procedure are shown in Figure 1. Following washing of the oral cavity with diluted povidone iodine and normal saline, a $10 \mathrm{~mm}$ transverse vestibular incision was made in the midline and extended in depth up to the mandible symphysis using an ultrasonic energy device SONICBEAT, USG 400 (Olympus, Tokyo, Japan) to dissect and divide the tissue and blood vessels [Figure 1A]. Using a Verse needle, sub-platysmal hydrodissection with approximately 20 $\mathrm{mL}$ of normal saline with adrenaline $(500 \mathrm{~mL}$ normal saline $+1 \mathrm{~mL}$ adrenaline) was performed in three axes (central, right and left) [Figure 1B]. Blunt dissection of the sub-platysmal plane with a blunt dilator was performed in the same three axes as the hydrodissection [Figure 1C]. A $10 \mathrm{~mm}$ central trocar for the camera was placed through the vestibular incision and insufflation was performed up to $5-6 \mathrm{mmHg}$ with carbon dioxide [Figure 1D]. Two additional $5 \mathrm{~mm}$ trocars were placed under direct vision through two $5 \mathrm{~mm}$ vertical incisions 

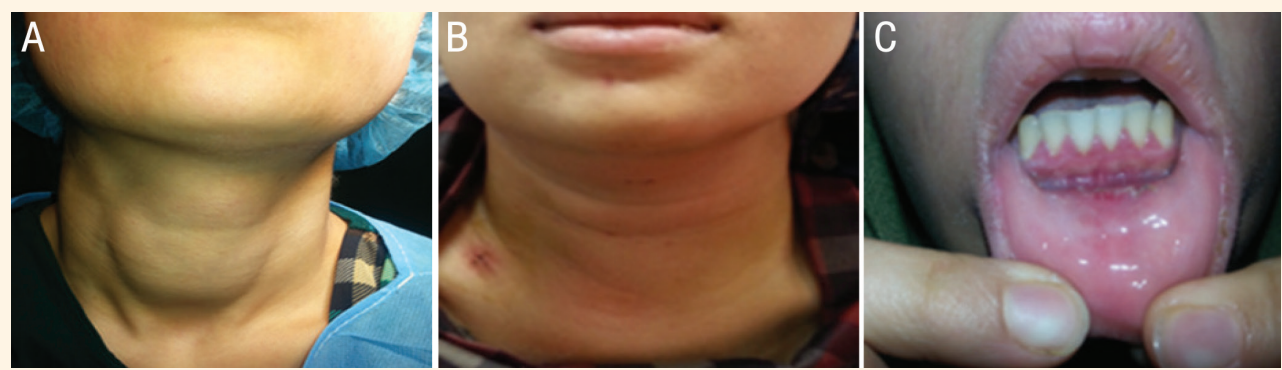

Figure 2: Photographs of the first patient in this report showing (A) her preoperative state and (B) one week post-transoral endoscopic thyroidectomy via vestibular approach with $(\mathbf{C})$ complete healing of the vestibular wound.

Table 2: Summary of intraoperative and post-operative outcomes and complications of ten patients who underwent transoral endoscopic thyroidectomy via vestibular approach at Al Shifa General Hospital, Basrah, Iraq

\begin{tabular}{|c|c|c|c|c|c|c|c|}
\hline Case $^{*}$ & $\begin{array}{l}\text { Type of thyroid } \\
\text { surgery }\end{array}$ & $\begin{array}{l}\text { Operative time } \\
\text { in minutes }\end{array}$ & $\begin{array}{l}\text { Duration of } \\
\text { drain removal } \\
\text { in hours }\end{array}$ & $\begin{array}{l}\text { Amount of } \\
\text { drainage } \\
\text { in } \mathrm{mL}\end{array}$ & $\begin{array}{l}\text { Duration of } \\
\text { hospital stay } \\
\text { in hours }\end{array}$ & $\begin{array}{c}\text { Final } \\
\text { pathology }\end{array}$ & Complication \\
\hline 1 & $\begin{array}{l}\text { Near total } \\
\text { lobectomy }\end{array}$ & 150 & 26 & 25 & 47 & $\mathrm{BCCD}$ & $\begin{array}{c}\text { Cervical } \\
\text { emphysema }\end{array}$ \\
\hline 2 & Lobectomy & 125 & 24 & 20 & 38 & $\mathrm{BCA}$ & $\begin{array}{l}\text { Temporary } \\
\text { mental nerve } \\
\text { palsy }\end{array}$ \\
\hline 3 & Lobectomy & 123 & 24 & 18 & 40 & BCA & None \\
\hline 4 & Lobectomy & 120 & 24 & 20 & 43 & $\mathrm{BCA}$ & None \\
\hline 5 & Lobectomy & 112 & 24 & 15 & 45 & $\mathrm{BCA}$ & None \\
\hline 6 & Lobectomy & 110 & 24 & 20 & 44 & BCA & None \\
\hline 7 & Lobectomy & 112 & 24 & 22 & 40 & $\mathrm{BCA}$ & None \\
\hline 8 & Lobectomy & 98 & 24 & 23 & 33 & $\mathrm{BCA}$ & None \\
\hline 9 & Lobectomy & 95 & 24 & 20 & 43 & BCA & None \\
\hline 10 & Lobectomy & 90 & 24 & 17 & 46 & BCA & None \\
\hline Average & & 113.5 & 24.2 & 20 & 41.9 & - & - \\
\hline
\end{tabular}

$B C C D=$ benign colloid cystic degeneration; $B C A=$ benign colloid adenoma.

"Inadvertent parathyroid removal was not observed in any of the cases.

in the most lateral aspects of either side of the vestibule nearest to the edges of the mouth [Figure 1E]. Using hanging sutures passing through the skin, the strap muscles were retracted laterally. The thyroid isthmus was dissected and transected. All thyroid blood vessels were divided as close to the thyroid as possible. Intraoperative neuromonitoring for the recurrent laryngeal nerve is not practised in Al Shifa General Hospital's surgical department and, therefore, anatomical landmarks were used to identify and preserve this nerve. All parathyroid glands were identified and preserved. The specimen was removed using an endobag via the $10 \mathrm{~mm}$ vestibular incision and sent for histopathology analysis.

If indicated, the same procedure was repeated on the left thyroid lobe. A redivac drain was inserted through the skin to drain the surgical field. Closure of the peritracheal fascia was performed using absorbable sutures and the vestibular wounds were closed in two layers with absorbable sutures. During removal of the endo- tracheal tube, the vocal cords were re-examined with flexible fibre-optic laryngoscopy to confirm normal function of the recurrent laryngeal nerve.

Intravenous antibiotics were continued until the patients were discharged from hospital. The drain was removed when the amount of post-operative drainage was less than $30 \mathrm{~mL}$ per day. The patients were discharged from hospital once the drain was removed, vital signs were within normal range, the patient could manage an oral diet and had been given instructions to continue oral antibiotics and mouthwash for one week. Patients were re-examined at the end of the first post-operative week at which time flexible fibre-optic laryngoscopy was again performed to evaluate vocal cord function. Subsequently, patients were re-examined after two, four and eight weeks. At the end of the follow-up period, the patients were asked whether they were satisfied with the results of this procedure and whether they would advise other patients to have the same procedure. 
Ten cases of TOETVA were successfully performed during the time-period without conversion to open thyroidectomy. The results of the ten cases are summarised in Tables 1 and 2. At the end of the follow-up period, all patients were satisfied with the excellent cosmetic results and stated that they would advise other patients to have the same surgery [Figure 2].

This report received approval of the local ethics committee. Informed consent was obtained from all patients and they were informed of the novel nature of this procedure and the associated risks that included the possibility of converting the TOETVA to an open thyroidectomy.

\section{Discussion}

All included patients were young and healthy females with a strong motivation for scar-free surgery. Most (90\%) had right-sided benign solitary thyroid nodules with the largest dimension ranging between $2-3.6 \mathrm{~cm}$. Based on the 2015 American Thyroid Association guidelines, some of these selected nodules can be observed safely without surgery. ${ }^{6}$ Since the current patients were not overweight and had anteriorly located nodules that are easily visible, they preferred the removal of these nodules with the scar-free TOETVA procedure for cosmetic reasons. The selection criteria of the current patients were consistent with the criteria described by Navarra et al. for novice TOETVA surgeons and to some degree, followed the early selection criteria described by Anuwong. ${ }^{4,5}$

In a review by Razavi et al's, all authors concluded that the primary indication for performing TOETVA is the patient's motivation to avoid neck scarring. ${ }^{7}$ Other indications identified include having a thyroid diameter $\leq 10 \mathrm{~cm}$ and a dominant nodule size $\leq 6 \mathrm{~cm}$, when benign or indeterminate, or a thyroid diameter $\leq 2 \mathrm{~cm}$, when malignancy is suspected or a well-differentiated thyroid cancer is confirmed. The recommended contraindications were having a history of neck surgery or neck irradiation, being unfit for general anaesthesia, showing evidence of uncontrolled hyperthyroidism, lymph node metastasis, extra-thyroidal extension, substernal thyroidal extension and presence of oral abscesses. Patients with thyroiditis and those with a high body mass index were considered relative contraindications.

In the current cases, an average operative time of 113.5 minutes was recorded. This result was comparable to the first results by Anuwong that reported an average operative time of 115.5 minutes. ${ }^{4}$ It was also comparable to the current literature on TOETVA that reports an average operative time of 115.4 minutes for subtotal thyroidectomy and 136.6 minutes for total thyroidectomy. ${ }^{8}$ A gradually decreasing operative time that reached 90 minutes in the tenth and last case was also recorded. This finding is consistent with the results by Razavi et al. who evaluated a series of 30 TOETVA patients, which concluded that the learning curve for TOETVA plateaus at 11 cases. ${ }^{9}$ They reported a significant reduction in the operative time over the first 11 cases after which the operative time remained steady with no significant changes. This is significantly shorter than the published learning curve for other remote access thyroidectomy and robotic thyroidectomy which is $20-50$ cases. $^{10-12}$

In this report, the surgeons were still inexperienced with this procedure and expected a high rate of post-operative haematoma. Therefore, a drain was used routinely as a precaution in all ten cases. In all cases, the drain was removed after a minimum of 24 hours with an average drainage volume of $20 \mathrm{~mL}$. The patients were discharged from hospital with an average stay of 41.9 hours. This differed from Anuwong who reported the use of a drain only after total thyroidectomy with TOETVA with an average drainage volume of $74.76 \mathrm{~mL}$ and an average duration of drain removal and hospital stay of approximately 72 hours. ${ }^{4}$

This report focused on the feasibility and safety of the TOETVA technique rather than the evaluation of post-operative pain. The post-operative score of TOETVA has been previously reported to be lower than that of open thyroidectomy. ${ }^{13}$ Another study found a difference in the profile pain scores between TOETVA and open thyroidectomy. ${ }^{14}$ Pain scores in the mental and vestibular area were higher in TOETVA while pain scores in the neck area were higher in open thyroidectomy. Patients had similar post-operative pain after TOETVA and open thyroidectomy on the fifth and seventh days and a similar post-operative stay in hospital (1.5 versus 1.6 days). ${ }^{14}$

With regard to the benefits of TOETVA in comparison to other remote access, robotic or open thyroidectomy approaches, the published literature demonstrated that TOETVA provides clear magnification of the operative field. This allows the surgeon to view the operative field in the craniocaudal direction, therefore permitting an approach to both thyroid lobes and identification of the recurrent laryngeal nerve early, near its insertion, which is the most constant part of the nerve. ${ }^{15-17}$ In addition, TOETVA is associated with less post-operative pain and only requires conventional laparoscopic instruments. ${ }^{15-17}$

The only recorded complications in the current cases were one case of mild cervical emphysema that resolved completely within 24 hours and another case showing symptoms of temporary mental nerve injury that resolved completely within four weeks. There were no reported cases of conversion to open thyroidectomy or mortality. The absence of other complications may 
be due to the small number of patients and to the careful selection of patients in this report. Camenzuli et al. published a systematic review of 16 studies on TOETVA with a total number of 785 patients. ${ }^{8}$ The overall reported complications were temporary recurrent transient post-operative hypocalcaemia (7.4\%), laryngeal nerve palsy (4.3\%), seroma (2.8\%), temporary mental nerve palsy (2.3\%), conversion to open thyroidectomy (1.3\%), subcutaneous emphysema (0.8\%), deep-seated neck infections $(0.6 \%)$, mediastinal emphysema (0.1\%), and operative site haematoma (0.1\%).

\section{Conclusion}

TOETVA is a safe and feasible procedure with an excellent cosmetic outcome. However, patients should be carefully selected especially during the surgeon's learning curve to avoid complications. At present, it is a relatively time-consuming procedure and, therefore, candidate patients with a strong motivation for scarfree surgery are recommended.

\section{References}

1. Witzel K, von Rahden BH, Kaminski C, Stein HJ. Transoral access for endoscopic thyroid resection. Surg Endosc 2008; 22:1871-5. https://doi.org/10.1007/s00464-007-9734-6.

2. Karakas E, Steinfeldt T, Gockel A, Mangalo A, Sesterhenn A, Bartsch DK. Transoral parathyroid surgery--a new alternative or nonsense? Langenbecks Arch Surg 2014; 399:741-5. https://doi.org/10. 1007/s00423-014-1187-5

3. Nakajo A, Arima H, Hirata M, Mizoguchi T, Kijima Y, Mori S, et al. Trans-Oral Video-Assisted Neck Surgery (TOVANS). A new transoral technique of endoscopic thyroidectomy with gasless premandible approach. Surg Endosc 2013; 27:1105-10. https://doi.org/10.1007/s00464-012-2588-6.

4. Anuwong A. Transoral endoscopic thyroidectomy vestibular approach: A series of the first 60 human cases. World J Surg 2016; 40:491-7. https://doi.org/10.1007/s00268-015-3320-1.

5. Navarra G, Bartolo V, Rizzo AG, Marullo M, Cancellieri A, Catalfamo A, et al. Pre- and post-operative patient care for transoral thyroidectomy. Ann Thyroid 2018; 3:3. https://doi.org/10.21 037/aot.2018.01.01.

6. Haugen BR, Alexander EK, Bible KC, Doherty GM, Mandel SJ, Nikiforov YE, et al. 2015 American Thyroid Association Management Guidelines for Adult Patients with Thyroid Nodules and Differentiated Thyroid Cancer: The American Thyroid Association Guidelines Task Force on Thyroid Nodules and Differentiated Thyroid Cancer. Thyroid 2016; 26:1-133. https://doi.org/10. 1089/thy.2015.0020.
7. Razavi CR, Russell JO. Indications and contraindications to transoral thyroidectomy. Ann Thyroid 2017; 2:12. https://doi.org/10. 21037/aot.2017.10.01.

8. Camenzuli C, Shembri Wismayer P, Calleja Agius J. Transoral endoscopic thyroidectomy: A systematic review of the practice so far. JSLS 2018; 22:e2018.00026. https://doi.org/10.4293/jsls. 2018.00026.

9. Razavi CR, Vasiliou E, Tufano RP, Russell JO. Learning curve for transoral endoscopic thyroid lobectomy. Otolaryngol Head Neck Surg 2018; 159:625-9. https://doi.org/10.1177/01945998 18795881.

10. Lee J, Yun JH, Nam KH, Soh EY, Chung WY. The learning curve for robotic thyroidectomy: A multicenter study. Ann Surg Oncol 2011; 18:226-32. https://doi.org/10.1245/s10434-0101220-z.

11. Yang J, Wang C, Li J, Yang W, Cao G, Wong HM, et al. Complete endoscopic thyroidectomy via oral vestibular approach versus areola approach for treatment of thyroid diseases. J Laparoendos Adv Surg Tech A 2015; 25:470-6. https://doi.org/10.1089/lap.20 15.0026

12. Park JH, Lee J, Hakim NA, Kim HY, Kang SW, Jeong JJ, et al. Robotic thyroidectomy learning curve for beginning surgeons with little or no experience of endoscopic surgery. Head Neck 2015; 37:1705-11. https://doi.org/10.1002/hed.23824.

13. Anuwong A. Post-operative pain control protocol for Transoral Endoscopic Thyroidectomy Vestibular Approach (TOETVA): Reply. Gland Surg 2017; 6:422-3. https://doi.org/10.21037/gs. 2017.06.02.

14. Dionigi G, Lavazza M, Pappalado V, Inversini D, Wu CW, Liu X, et al. OP35 -Transoral Endoscopic Thyroidectomy Vestibular Approach (TOETVA) or open thyroidectomy: A prospective randomised trial to compare length of stay and postoperative pain. From: https://thyroidworldcongress.com/presentation/op35-transoral-endoscopic-thyroidectomy-vestibularapproach-toetva-or-open-thyroidectomy-a-prospectiverandomised-trial-to-compare-length-of-stay-andpostoperative-pain/ Accessed: Nov 2018

15. Russell JO, Clark J, Noureldine SI, Anuwong A, Al Khadem MG, Yub Kim H, et al. Transoral thyroidectomy and parathyroidectomy - a North American series of robotic and endoscopic transoral approaches to the central neck. Oral Oncol 2017; 71:75-80. https://doi.org/10.1016/j.oraloncology.2017.06.001.

16. Jitpratoom P, Ketwong K, Sasanakietkul T, Anuwong A. Transoral Endoscopic Thyroidectomy Vestibular Approach (TOETVA) for Graves' disease: A comparison of surgical results with open thyroidectomy. Gland Surg 2016; 5:546-52. https://doi.org/10.21 037/gs.2016.11.04.

17. Anuwong A, Kim HY, Dionigi G. Transoral endoscopic thyroidectomy using vestibular approach: Updates and evidences. Gland Surg 2017; 6:277-84. https://doi.org/10.21037/gs.2017.03.16. 